Buoyancy of Bodies in Water

In NATURE, vol. xxiv. p. 166, Dr. W. Curran says:- "It is, I think, generally assumed in books and courts of law that all bodies, human and bestial, sink as a rule in water as soon as life is extinct." How far this statement may be true as regards animals generally, I am not prepared to say, but it certainly does not hold good as regards the reindeer. The Eskimos spear many reindeer whilst crossing lakes, and it sometimes occupies them an hour or two in "towing" them all to land, yet it is a rare exception that any are lost by sinking, even of the full-grown males, which in autumn are heavily weighted with large antlers. 4, Addison Gardens, June 25

JOHN RAE

\section{An Optical Illusion}

WiLL you allow me to add something to the letter from William Wilson in NAT URE, vol, xxiv. p. 53 .

I. The results described may be produced without bending the card or using a square hole. A flat card, with a pin-hole, is held some distance from the eye, and a pin moved so as to be in a right line between the eye and the hole; the results described by $\mathrm{Mr}$. Wilson follow. 2. Some few trials may be necessary in order to get a clear image (if this is the proper term), but it will be found that considerable variation in the distances from the eye to the pin and from the pin to the hole can occur without destroying the effect. 3. The image seems to me to be close to the card in every case, while the distance from the eye to the card may vary a great deal.

Clarence M. Boutelle

State Normal School, Winona, Minn., U.S., June 10

\section{Resonance of the Mouth-Cavity}

In reply to $\mathrm{Mr}$. George J. Romanes, I beg to say that the object of my communication printed in NATURE, vol. xxiv. p. 100, was to show that the mouth-cavity will give a distinct resonance to different rates of vibration already in the air by being shaped suitably for each of them (and providing they come within its limit). The mouth thus gives the means of analysing the com posite nature of sound. Any one successfully repeating my experiments given on pp. 100, 126, would be satisfied that they pointed to something different to the boys' amusement mentioned in Mr. Romanes' letter (p. I66).

5, West Park Terrace, Scarborough

JOHN NAYLOR

\section{American Cretaceous Flora}

IN several of the interesting and valuable papers on the Tertiary flora which Mr. J. Starkie Gardner has contributed to the English journals he has referred to the fossil plants in our Cre. taceous rocks as representing a flora really Tertiary in character and, influenced by the modern aspect of the plants contained in our Dakota group (Lower Cretaceous), he has expressed a doubt whether even that should be regarded as truly of Cretaceous age. In a former number of NATURE I endeavoured to show that our Dakota flcra was Cretaceous, inasmuch as it is found in rucks which are overlain by several thousand feet of strata containing many mollusks, fishes, and reptiles which are everywhere recognised as Cretaceous, and none that are Tertiary.

Mr. Gardner was not however convinced by my facts or arguments, and in the April number of the Popular Science Review he reiterates and emphasises his formerly expressed opinion, referring all our Cretaceous strata to the Maestricht beds, and intimating that, in common with that formation, they should be separated from the Cretaceous system. His language is as follows :-

"The presence of Mosasaurus in the Maestricht beds, and the far newer aspect of its fauna, show that it mut have belonged to an altogether different feriod, probably the one represented in America by a great so-called Cretaceous series containing a mixture of Cretaceous and Tertiary mollusks, dicotyledonous plants, and Mosasaurus. . . .

"No American or European so-called Cretaceous land flora can be proved to be as old as our White Chalk."

Now in no spirit of criticism, for I appreciate and value the excellent work that Mr. Gardner is doing, but simply for the vindication of the truth of geology, I ask him to qualify these statements.

I am imfelled to this course by the following facts :-

In our Triassic series we have in some places beds of coal and the remains of a vegetation decidedly Mesozoic in character, consisting of Cycads, Conifers, and Ferns, but, as far as we yet know, without a single Angiosperm.

In the Jurassic age the eastern half of the North American Continent formed a land-surface, for the secliments of the Jurassic sea are confined to a somewhat irregular area in and west of the Rocky Mountain belt.

Of the Jurassic flora of North America we as yet know little or nothing; but the continent that bordered the Jurassic sea ultimately became covered with a new, varied, and highly. organised flora, of which the origin is yct unknown.

In the Cretaceous age all the continent lying east of the Wasatch Mountains was affected by a subsidence which brought the sea in from the Gulf of Mexico with a front Ioco miles wide, and the great inland sea thus formed gradually extended northward till it reached nearly, if not quite, to the present shore of the Arctic Ocean.

The waves of the Cretaceous sea in their advance swept before them a shore that was covered with a luxuriant forest of at least one hundred species of Angiospermous trees; and the remains of trunks and twigs, leaves and fruit, were buried up in the sheet of beach material which accumulated all along the advancing : hore line, and which now forms the Sandstones of the Dakota group. Uj to the present time very few mollusks have been found in this group, and they are not sufficient to fix with exactness its relation to the Cretaceous series of other countries. The plants, too, are distinct from any found in Europe, though they include, with many extinct forms, genera which are common in the living forests of America, such as Quercus salix, Magnolia, Fagus, Liquidambar, Liriodendron, \&c.

When the subsidence which produced the Dakota group was at its maximum the sea stood several thousand feet deep over the central portion of the trough between the Alleghanies and the Wasatch Mountains, and here we now find at least two thousand feet of marine, calcareous, organic sediment, which have furnished hundreds of species characteristic of the Cretaceous age, and a large number that are identical with those contained in the Upper Greensand and Chalk of Europe.

It is true that up to the present time no Neocomian fossils have been found in the interior of the Continent, but with that exception the entire Cretaceous series of the Old World is represented there. Hence it is not true that our Cretaceous "con. tains nothing so old as the Chalk."

Nor is it true, as intimated by Mr. Gardner, that our "socalled Cretaceous rocks" contain a Tertiary flora and fauna, as no Tertiary species of either has yet been found there. The flora of the Dakota group is more modern in its aspect than that of the Lower and Middle Cretaceous of Europe, but its plants are specifically different from any found in Europe in our Middle Cretaceous (Colorado group), Upper Cretaceous (Laramie group), or Tertiary beds (of Green River, Fort Union, and Oregon). The facts apparently indicate that the earliest development of Angiospermous plant-life took place here, and this in a temperate fora of which the descendants long afterwards-in Tertiary times-occupied Greenland, Spitzbergen, \&c., and spread by land connections into Europe and Asia.

The best authorities we have had on questions relating to the Cretaceous fama-Messrs Gabb and Meek-were fully agreed in regarding our Middle Cretaceous as of the age of the Chalk. Mr. Gabb divided the Cretaceous series of California into four members-

$$
\begin{aligned}
& \text { 1. The Tejou group. } \\
& \text { 2. The Martinez group. } \\
& \text { 3. The Chico group. } \\
& \text { 4. The Shasta group. }
\end{aligned}
$$

Of these the oldest, or Shasta, group was regarded by him as of Neocomian age, the Chico and Martinez groups-which should perhaps be united-as the representatives of the Upper and Lower Chalk, and the Tejou group as the equivalent of the Maestricht beds,

The coal-beds and the fossil plants of Vancouver's Island lie at the base of the Cretaceous series as it exists there, and the molluscous remains indicate that it is the equivalent of the Chico group. The plants are apparently all distinct from those of the Dakota group of the interior. They include palms and cinnamons, and evidently grew in a warmer climate than that $v$ hich produced the temperate flora of the Lower Cretaceous of Kansas, Nebraska, and the Atlantic coast.

Among the Vancouver Island Cretaceous plants is one wellknown species, sequoia Reichtnbachii, H., which is found in 